\title{
The Impact of COVID-19 Pandemic on Uganda's Balance of Trade between April 2020 and April 2021
}

\author{
Richard Wemesa ${ }^{*}$, Christopher Wagima², Ivan Bakaki², Phiona Nanfuka ${ }^{2}$, Alex Madolo ${ }^{3}$, \\ Stephen Mukooba ${ }^{3}$, Patrice Ocungirwoth ${ }^{3}$, Allan Matsiko ${ }^{3}$, Ngobi John ${ }^{4}$, Sam Engola ${ }^{4}$
}

\begin{abstract}
${ }^{1}$ Faculty of Business and Management, International University of East Arica (IUEA), Associate Lecturer and Head Research and Innovation at The Uganda Institute of Banking \& Financial Services and Senior Lecturer Unicaf University, Kampala, Uganda ${ }^{2}$ Faculty of Business \& Management, International University of East Africa, Kampala, Uganda

${ }^{3}$ The Uganda Institute of Banking and Financial Services/UIBFS, Kampala, Uganda

${ }^{4}$ Seeta High School, Green Campus, Kampala, Uganda

Email: ^Richie.wemesa@gmail.com, ^Richard.wemesa@iuea.ac.ug, Christopher.wagima@iuea.ac.ug, Ivan.bakaki@iuea.ac.ug, Phiona.nanfuka@iuea.ac.ug, madoloalex@gmail.comg, stephenmukooa@yahoo.com, kernerpat@gmail.com, amatsiko02@gmail.com, bridgetnassonko@gmail.com,ngobi.jb@gmail.comngobijohnbap@yahoo.com, engolasamlamailing@gmail.com
\end{abstract}

How to cite this paper: Wemesa, R., Wagima, C., Bakaki, I., Nanfuka, P., Madolo, A., Mukooba, S., Ocungirwoth, P., Matsiko, A., John, N., \& Engola, S. (2021). The Impact of COVID-19 Pandemic on Uganda's Balance of Trade between April 2020 and April 2021. Open Journal of Business and Management, 9, 2674-2682.

https://doi.org/10.4236/ojbm.2021.96147

Received: September 6, 2021

Accepted: October 23, 2021

Published: October 26, 2021

Copyright $\odot 2021$ by author(s) and Scientific Research Publishing Inc. This work is licensed under the Creative Commons Attribution International License (CC BY 4.0).

http://creativecommons.org/licenses/by/4.0/

Open Access

\begin{abstract}
The coronavirus pandemic (COVID-19) has been categorized as the worst health crisis of our times with a fatality rate of 5 percent and over 10 million people infected around the world by June 2020. Several nations worldwide put in place desperate measures, including complete national lockdowns and travel restrictions to try and contain the virus. This distorted global supply chains and adversely affected global growth. Uganda is no exception to the pandemic as the adverse effects have already started to ripple through the trade balance of the domestic economy. This paper contributes to the dearth of studies on the effect of COVID-19 pandemic on Uganda's trade balance between April 2020 and April 2021. Purpose: The aim of this paper is to offer a critical analysis of the impact of COVID-19 on Uganda's balance of trade. Methodological approach to the study: This paper in its analysis employed a Descriptive research design of the monthly trade data at a household, firm and national level. Findings: COVID-19 Pandemic caused a temporary short to medium term disequilibrium in Uganda's balance. The containment measures adopted by the government of Uganda to curb the further spread of the virus specifically the first lock down announced on $26^{\text {th }}$ March 2020 by his excellence the president of the republic of Uganda motivated by the first of the pandemic caused a sharp disruption of Uganda's balance of trade. Implication: The nature of the disequilibrium in Uganda's balance of trade of goods and services can fully recover swiftly when the crisis caused by the pandemic
\end{abstract}


comes to an end. However, the COVID-19 Pandemic may have a stretched long-term impact on Uganda's balance of trade in goods and services that heavily rely on the movement of commercial traders. Originality of the paper: The paper contributes to the existing body of knowledge in aiding to understand how COVID-19 has impacted on Uganda's balance of trade of goods and services.

\section{Keywords}

COVID-19, Balance of Trade, Goods and Services

\section{Introduction}

To be exact on $31^{\text {st }}$ Dec. 2021, the streets of Uganda's Capital Kampala were filled to capacity with copies of the RED PEPPER Newspaper, a celebrated local Newspaper in Uganda's capital of Kampala whose headline bolded in red color read as "Go to hell 2020". This headline was a head-on curse for the year 2020 to go to hell and be consumed by its everlasting flames of fire. Cursing the year 2020 by this local celebrated social newspaper was motivated by the fact that the COVID-19 pandemic outbreak in March 2020 had caused a global health emergency which had paralyzed every sector of the global economy including Uganda's financial services, manufacturing, transport, education sectors (Source, Researcher's own statement)

Coronavirus is a collection of viruses that can infect the respiratory system. In many cases, this virus causes minor respiratory infections, such as flu. However, this virus can also cause severe respiratory infections, such as lung infections (pneumonia), Middle-East Respiratory Syndrome (MERS), and severe acute respiratory syndrome (SARS). This disease that attacks the body's respiratory and immune systems is called Covid-19 (Ratnadi H. Wicaksana et al., 2021). Initially, the perception was that COVID-19 pandemic would be localized only in Chinese district of Wuhan, but this was not the case, as later, the pandemic fever caught the entire global motivated by the movement of people (Wemesa et al., 2020). The virus has today infected more than 51 million and killed almost 1.3 million people globally. To avert the spread of the virus, several governments have introduced strict social distancing and containment measures, and these have had a large negative impact on global economic activity (Minondo, 2020).

For example, mitigation measures that minimize COVID-19 associated morbidity and fatalities have resulted in economic losses and a decline in global economic activity. For example, the tourism and hospitality industry a major foreign exchange earner for Kenya suffered huge losses due to global restriction of movement (Wangari, Gichuki, Abuor et al., 2021).

\section{External Trade Balance}

Uganda's external position has been largely characterized by a relatively large 
current account deficit that has been largely funded by the surpluses in the financial account. In the 12 months to April 2020, the current account deficit narrowed US $\$ 2.32$ billion. This improvement was partly driven by a reduction in the import bill by US $\$ 231.1$ million and a US $\$ 89.3$ million decline in export receipts (Bank of Uganda, 2020). However, during the months under lockdown, the current account deficit worsened. Indeed, comparing external sector outturns in the two months of March and April 2020 to those of January and February 2020 , current account deficit worsened by 12.4 percent, exports declined by 29.6 percent, imports by 27.4 percent, workers remittances by 41.5 percent, tourism receipts by 85.4 percent and FDI by 5.6 percent.

The Ugandan economy is more vulnerable to the world trade cycle because her exports are highly dependent on advanced economies' demand. Uganda's exports could therefore decline drastically since the virus has spread rapidly in Uganda's major trading partners. In COMESA for example, trade has been restricted as most countries instituted strict movement controls in an effort to contain the spread of the virus and a few have only started lifting these controls in phases. In addition, commodity prices have declined sharply. Nonetheless, whereas a decline in oil prices is beneficial to Uganda as an oil importer, the detrimental effect caused by decline in agricultural commodity prices, such as coffee, outweighs the benefits of oil price decline.

\section{Methodology}

This paper adopted a Qualitative research approach and specifically the paper employed Descriptive research approach which involves gathering data that describe events and then organizes, tabulates, depicts, and describes the data collection (Glass \& Hopkins, 1984). This research design was opted for because it often uses visual aids such as graphs and charts to aid the reader in understanding the data distribution and this method very important in reducing the data to manageable forms of organized data patterns that emerge during analysis. Those patterns aid the mind in comprehending a qualitative study and its implications.

\section{Data Presentation \& Analysis}

\subsection{Uganda's Merchandise Exports and Imports - April 2020 and April 2021}

Merchandise export receipts more than doubled on an annual basis, but declined on a monthly basis. Export receipts rose by 106\% (USD 219.51 million) from USD 207.05 million in April 2020 to USD 426.56 million in April 2021. This increase followed the lifting of lock down measures that disrupted transport in April 2020. April 2020 was the month Uganda experienced a total lockdown, which led to a sharp decline in export earnings at the time. Nearly all export items registered a rise in their earnings with coffee and mineral exports recording the largest increases (Table 1, Table 2, Figure 1). 
Table 1. Impact of Covid-19 on the external position.

\begin{tabular}{|c|c|c|c|c|c|}
\hline $\begin{array}{c}\text { Item (in US\$ } \\
\text { million unless } \\
\text { Stated otherwise) }\end{array}$ & $\begin{array}{l}\text { FY 2019/20 } \\
\text { (Initial } \\
\text { Projection) }\end{array}$ & $\begin{array}{l}\text { FY 2019/20 } \\
\text { (Current } \\
\text { Projection) }\end{array}$ & $\begin{array}{c}\text { Percentage } \\
\text { Change }\end{array}$ & $\begin{array}{l}\text { FY 2020/21 } \\
\text { (Current } \\
\text { Projection) }\end{array}$ & $\begin{array}{l}\text { Percentage } \\
\text { Change }\end{array}$ \\
\hline Current Account & -2850.8 & -2590.1 & -9.1 & -3835.4 & 48.1 \\
\hline Exports & 3696.5 & 3536.6 & -4.3 & 3566.4 & 0.8 \\
\hline Imports & 6396.3 & 5871.8 & -8.2 & 6431.1 & 9.5 \\
\hline $\begin{array}{l}\text { Travel Credits } \\
\text { (Tourism) }\end{array}$ & 1209.0 & 817.6 & -32.4 & 171.7 & -79.0 \\
\hline $\begin{array}{l}\text { Personal } \\
\text { Transfers }\end{array}$ & 1153.5 & 1186.5 & 2.9 & 550.8 & -53.6 \\
\hline FDI & 1184.0 & 988.2 & -16.5 & 858.2 & -13.2 \\
\hline $\begin{array}{c}\text { Loan } \\
\text { Disbursements }\end{array}$ & 2153.9 & 2153.9 & -47.7 & 2495.0 & 121.5 \\
\hline Reserves & 4.2 & 4.0 & & 3.2 & \\
\hline
\end{tabular}

Source: Bank of Uganda, 2020.

Table 2. Merchandise Exports by product, Million USD, (Source: BoU and MFPED Calculations).

\begin{tabular}{|c|c|c|c|}
\hline & April 2020 & March 2021 & April 2021 \\
\hline Total exports & 207.05 & 444.08 & 426.56 \\
\hline 1. Coffee (Value) & 36.93 & 53.52 & 50.02 \\
\hline Coffee (60 kg bags) & 359,973 & 572,837 & 537,538 \\
\hline Av. unit value & 1.71 & 1.56 & 1.55 \\
\hline 2. non-Coffee formal exports & 169.20 & 362.18 & 348.51 \\
\hline $\mathrm{o} / \mathrm{w}$ Mineral exports & 60.42 & 155.69 & 175.61 \\
\hline Cotton & 0.72 & 4.25 & 2.85 \\
\hline Base Metals \& Products & 5.50 & 12.45 & 10.25 \\
\hline Tobacco & 2.59 & 9.14 & 4.95 \\
\hline Fish \& its prod. (excl. regional) & 6.76 & 8.59 & 8.09 \\
\hline Hides \& skins & 0.36 & 0.95 & 2.59 \\
\hline Beer & 1.35 & 3.17 & 1.60 \\
\hline Maize & 6.18 & 5.38 & 3.06 \\
\hline Beans & 0.60 & 5.26 & 3.52 \\
\hline Cement & 5.81 & 7.73 & 7.00 \\
\hline Cocoa beans & 6.15 & 13.27 & 10.34 \\
\hline 3. ICBT Exports & 0.92 & 28.37 & 28.03 \\
\hline ports excluding mineral exports & 146.63 & 288.38 & 250.95 \\
\hline
\end{tabular}

Source: Bou and MFPED, May 2021 Performance of the economy report. 


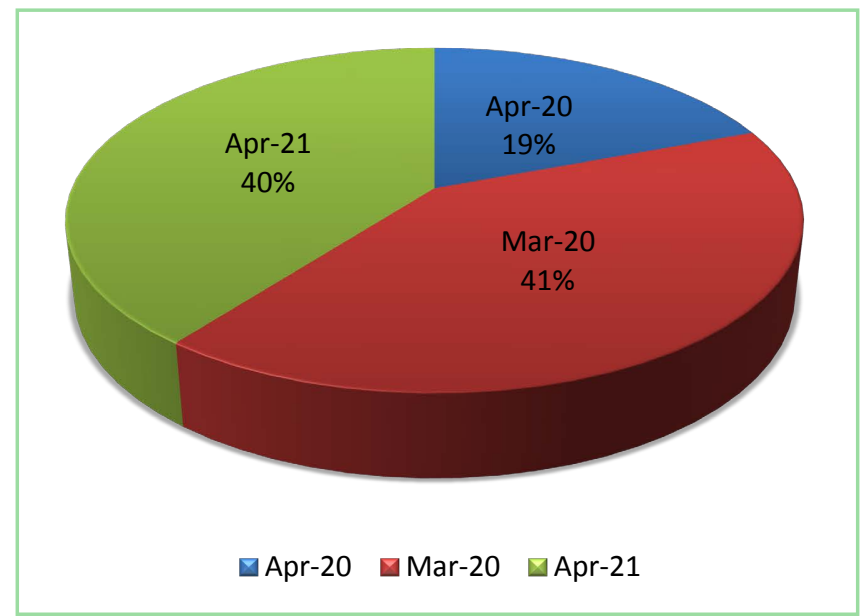

Figure 1. Total Merchandise Exports by product, million USD. Source: Bou and MFPED Calculations, May 2021.

Compared to March 2021, there was a decline in export earnings which fell by 3.9\% to USD 426.56 million in April 2021 from USD 444.08 million. This decrease followed lower export earnings of tobacco, coffee, cocoa beans, beer, cotton, base metals \& products following a decline in their respective volumes. Merchandise exports excluding mineral exports recorded an increase in export earnings on an annual basis and a decline on a monthly basis. On an annual basis, export earnings excluding mineral exports saw a $71 \%$ increase from USD 146.63 million in April 2020 to USD 250.95 million in April 2021. On the other hand, export earnings excluding mineral exports decreased from USD 288.38 million in March 2021 to USD 250.95 million in April 2021 (Table 1, Table 2, Figure 1).

\subsection{Uganda's Destination of Merchandise Exports}

During April 2021, the Middle East was Uganda's top destination for merchandise exports, followed by the East African Community, the Rest of Africa and European Union. The value of exports to the Middle East nearly tripled from USD 61.91 million in April 2020 to USD 179.64 million in April 2021, mainly due to an increase in the export of minerals (Figure 2).

\subsection{Uganda's Merchandise Imports}

The value of merchandise imports registered a third consecutive monthly increase in April 2021. Merchandise worth USD 695.81 million were imported in April 2021, registering an increment of 5.3\% from the previous month. The increase was mainly driven by higher volumes of merchandise imported by the private sector as economic activity continued to pick up. In comparison with April 2020, the value of merchandise imports increased from USD 342.50 million to USD 695.81 million (103.2\%). This was mainly due to removal of lockdown measures and restrictions (Table 3 ). 
Asia remained the biggest source of merchandise imported in April 2021 accounting for $36 \%$ of the total imports. Merchandise imported from the EAC and the Middle East contributed $28 \%$ and $11 \%$ of the total imports, making them the second and third largest sources of imports. Within the EAC, Tanzania and Kenya accounted for the largest share of imports at $65 \%$ and $34 \%$ respectively (Figure 3).

Uganda traded at a deficit with the regions except for the Middle East with which a trade surplus of USD 99.70 million was recorded in April 2021. In contrast with the previous month, Uganda's trade with the Rest of Africa resulted in a deficit owing to increased imports sourced from the region in April 2021 (Table 4).
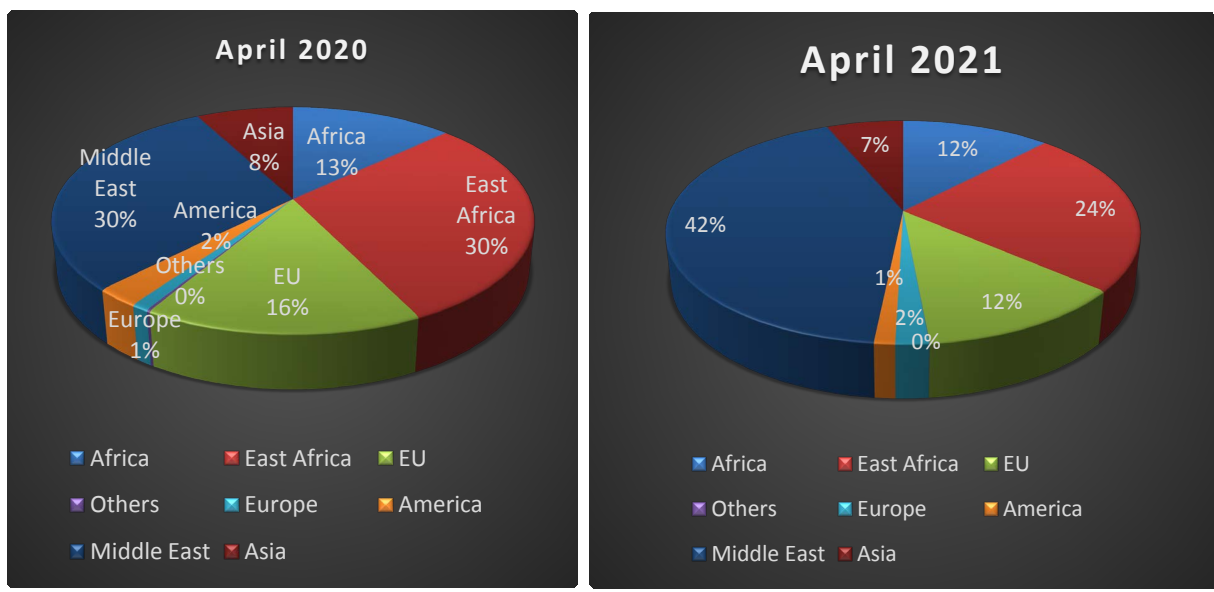

Figure 2. Merchandise exports by destination (Source: BoU).

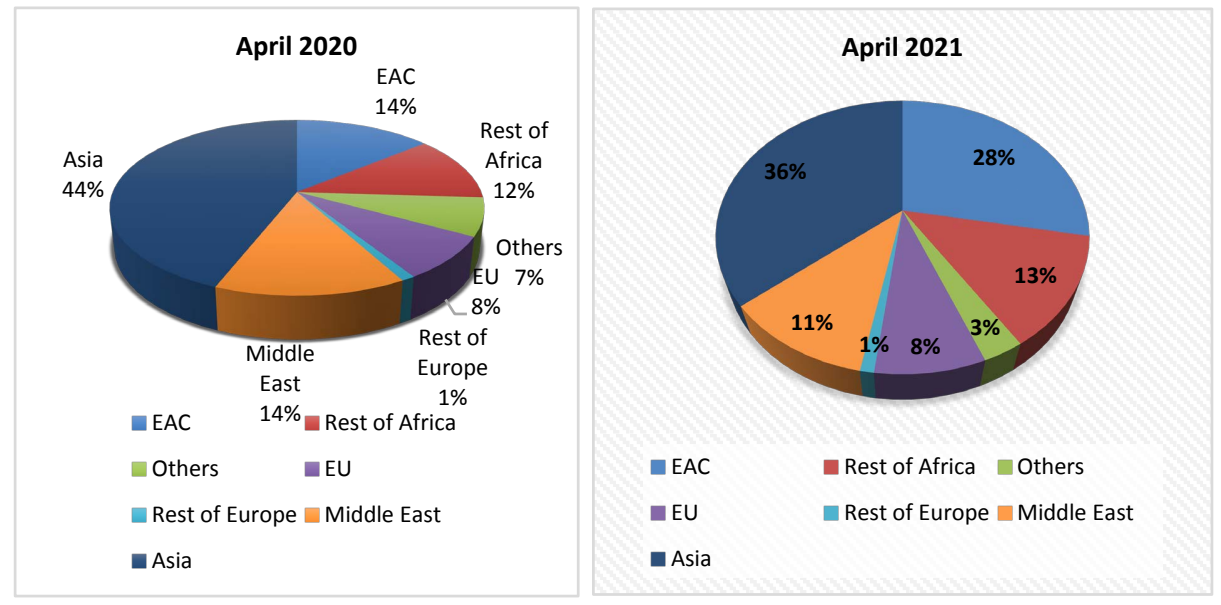

Figure 3. Uganda's Merchandise imports by region (source: BoU).

Table 3. Uganda's Merchandise imports April 2020 and April 2021.

\begin{tabular}{cccc}
\hline Period & Apr-2020 & Mar-2021 & Apr-2021 \\
\hline Value of merchandise imports & 342.50 & 658.93 & 695.81 \\
\hline
\end{tabular}

Source: BoU May 2021 Performance of the economy report. 
Table 4. Merchandise Trade balance by region.

\begin{tabular}{cccc}
\hline Trade balance by region & April 2020 & March 2021 & April 2021 \\
\hline European Union & 4.7 & -25.2 & -5.7 \\
Rest of Europe & -1.2 & -2.7 & -0.8 \\
Middle East & 13.7 & 78.1 & 99.7 \\
Asia & -135.6 & -237.6 & -222.3 \\
East Africa & 15.2 & -30.8 & -90.5 \\
Rest of Africa & -13.9 & 19.7 & 35.1 \\
The America and Others & 18.4 & -17.9 & -14.5
\end{tabular}

Source: Merchandise Trade balance by region, by Million USD (Source, Bou).

\section{Recommended Recovery Strategies (Table 5)}

Table 5. Immediate to short term and Medium to Long Term recovery strategies of Uganda's trade balance.

Immediate to Short term Medium to Long Term

- Uganda in partnership with its other East African Community member states to source for alternative markets for EAC imports and exports to reduce dependence on a few countries.

- Uganda in partnership with regional states to consider a regional coordinated approach on mitigating the impact of COVID-19.

- Uganda in partnership with other regional states to consider improving the business and regulatory environment to ease the formulization of the businesses in member partner states.

- Uganda in partnership with other regional - Uganda in partnership with regional states states to consider allowing free movement of both, essential and non-essential trade of goods and services within and outside the East African Community.

- Uganda should embrace use of online technological conduct of business to consider for the policy agenda of Buy East Africa Build East Africa. This can cushion Uganda and any other member states from the negative impacts of COVID-19. transactions both within and outside the EAC.

- Uganda to increase its facilitation of the private sector in order to increase production of

- Uganda in partnership with regional manufactured goods in East Africa. states to consider adding more health worker resources at the boarders to - a regional coordinated approach on facilitate efficient and mitigating the impact of COVID-19. effective.

- regional coordinated approach on mitigating the impact of COVID-19.

Source: Own suggested recommended recovery strategies.

\section{Discussion}

Bank of Uganda and Ministry of Finance, Planning and Economic Development 
monthly Performance of the economy reports between April 2020 and April 2021 where short of any recommended recovery strategies both immediate to short term and Medium to Long Term recovery strategies of Uganda's trade balance. This paper provides a comprehensive descriptive trade balance position of Uganda between April 2020 and 2021 and suggests recommended recovery strategies of Uganda's economy ranging from immediate to short term and medium to long term recovery strategies

\section{Conclusion}

COVID-19 has caused a remarkable disequilibrium in Uganda's balance of trade. However, the containment measures adopted by the government of Uganda to curb the further spread of the virus specifically the first and second lock downs announced on $26^{\text {th }}$ march 2020 and $18^{\text {th }}$ June 2021 motivated by the first and second waves respectively of the pandemic have caused a moderate disruption of Uganda's balance of trade in goods and services specifically in the first and second quarter of 2020. The disruption of Uganda's balance of trade in goods and services, which entirely affected top exporters in the country, suggests a fast recovery of Uganda's trade balance when the health crisis comes to an end. However, the recovery of the tourism sector may take longer than anticipated because it depends on the perception of tourists intending to visit Uganda. In addition to the short term disequibrium in the balance of trade of Uganda's goods and services, COVID-19 might have long term impact on Uganda's trade balance. Uganda must develop strategies to reduce its dependence on foreign tourism earnings and exploit opportunities to expand business exports.

\section{Objective of This Paper}

The objective of this short paper is to provide realistic analysis of the impact of COVID-19 on Uganda's balance of trade of goods and services from April 2020 to April 2021.

\section{Conflicts of Interest}

The authors declare no conflicts of interest regarding the publication of this paper.

\section{References}

Bank of Uganda (BoU) (2020, June). Monetary Policy Report. https://www.bou.or.ug/bou/bouwebsite/bouwebsitecontent/MonetaryPolicy/Monetary _Policy Reports/2020/Jun/MPR_June 2020.docx.pdf

Glass, G. V., \& Hopkins, K. D. (1984). Statistical Methods in Education and Psychology. (2nd ed.). Prentice-Hall.

Minondo, A. (2020). Impact of COVID-19 on the Trade of Goods and Services in Spain. arXiv:2012.01903 [econ.GN]

Wangari, E. N., Gichuki, P., Abuor, A. A. et al. (2021). Kenya's Response to the COVID- 
19 Pandemic: A Balance between Minimizing Morbidity and Adverse Economic Impact. AAS Open Research, 4, 3.

Wemesa, R., Wagima, C., Bakaki, I,. \& Turyareeba, D. (2020). The Economic Impact of the Lockdown Due to COVID-19 Pandemic on Low Income Households of the Five Divisions of Kampala District in Uganda. Open Journal of Business and Management, 8, 1560-1566. https://doi.org/10.4236/ojbm.2020.84099

Wicaksana, R. H. et al. (2021). Trade Balance during the Covid-19 Pandemic. IOP Conference Series: Earth and Environmental Science, 716, Article ID: 012077. https://doi.org/10.1088/1755-1315/716/1/012077

\section{Website}

https://www.bou.or.ug

https://www.finance.go.ug/ 